\title{
The source of teacher work stress: a factor analysis approach
}

\author{
Arismunandar*, Nurhikmah H, Andi Wahed, Hengki Wijaya, Hasnawi Haris \\ Universitas Negeri Makassar, Indonesia \\ *Corresponding Author: arismunandar@unm.ac.id
}

\begin{abstract}
This research is motivated by work stress among teachers with various negative impacts on physical, mental, and performance health. The purpose of the study was to determine the levels of teacher work stress and its sources in South Sulawesi. This research is is a survey research with teachers in South Sulawesi as the subject of the research. Data were collected using a questionnaire and were analyzed using the quantitative data analysis. Findings showed that teacher work stress in South Sulawesi was moderate, with a data trend of $41.9 \%$. Teacher work stress is due to six sources of work stress, namely (1) welfare; (2) teaching; (3) students; (4) relationships and conflicts; (5) organizational climate; and (6) the time dimension. The dominant or general source of teacher work stress comes from welfare and teaching factors, while other teacher work stress factors are student factors and organizational climate. Findings from the factor analysis shows that the six indicators are combined in only one factor in the work stress source variable.
\end{abstract}

Keywords: level of stress, sources of teacher work stress, South Sulawesi Article history

$\begin{array}{llll}\text { Received: } & \text { Revised: } & \text { Accepted: } & \text { Published: } \\ 20 \text { October 2021 } & \text { 24 December 2021 } & \text { 16 January 2022 } & \text { 20 February 2022 }\end{array}$

Citation (APA Style): Arismunandar, A., Nurhikmah, H., Wahed, A., Haris, H. (2022). The source of teacher work stress: a factor analysis approach. Cakrawala Pendidikan: Jurnal Ilmiah Pendidikan, 41(1), $112-128$. https://doi.org/10.21831/cp.v41i1.41611

\section{INTRODUCTION}

In the last few decades, there has been growing interest among experts in various disciplines to study the phenomenon of work stress. Due to high job pressure and low resources, teacher stress and burnout are increasing in urban schools (Bottiani, Duran, Pas, \& Bradshaw, 2019). Several reasons for the causes of work stress are revealed in the study. Life stress and work stress are fatigue factors. The pressure of work as a teacher can cause burnout (Pogere, López-Sangil, García-Señorán, \& González, 2019; Wu, Tseng, Tseng, Chen, Pai, \& Yen, 2021). Low student involvement, motivation, and negative teacher-student relationships (Junker, Donker, \& Mainhard, 2021). Sound disturbances, stress in the classroom, the poor classroom environment can reduce the ability of teachers (Burman \& Goswami, 2018; Vertanen-Greis, Loyttyniemi, Uitti, \& Putus, 2020). Low teacher efficacy and high depression are reported to cause high teacher stress (Herman, Prewett, Eddy, Savala, \& Reinke, 2020). Due to lack of social support, teacher stress affects teacher career attitudes (Taylor, McLean, Bryce, Abry, \& Granger, 2019). However, during the Covid-19 period, work stress became the focus for psychological recovery (Mo, Deng, Zhang, Lang, Liao, Wang, Qin, \& Huang, 2020).

Teacher work stress has impacted on teachers' mental and physical health. The results of the path analysis test conducted by Zong et.al (2009) state that fatigue is a mediator between work stress, the occurrence of annoyance as a symptom of depression, and poor physical health. One example of the impact of work stress on phisical health is muscle pain (Putri, Rahmaniar S.P., \& Djayanti, 2020). 
Numerous studies have also shown that teachers' performances are also at risk due to stress. For example, Anandasayanan, \& Subramaniam (2013) found in their research that teacher stress has a significant impact on teacher performance. Previous research has also found that stress and job satisfaction are negatively correlated; High job stress is associated with lower levels of job satisfaction (Chaplain, 2006).

Research among school teachers in South Sulawesi also found that the percentage of teachers who experienced severe stress (high and very high) 30.27 percent. At the same time, teachers who experienced moderate work stress were 48.11 percent. And those who experience less severe work stress are 21.62 percent (Arismunandar, 1997). Arismunandar further, research conducted several years later, showed that as many as 25.2 percent of the 377 samples of elementary school teachers in South Sulawesi experienced high or severe work stress, 41.9 percent experienced moderate stress 32.9 percent experienced low-stress work (Arismunandar, 2000).

Work stress is used to indicate the stressful state experienced by an individual, which is caused by certain conditions or situations that occur in his work environment. The term distinguishes it from other types of life stress that originates from the family environment and social environment (Robbins, 2003). Of the three approaches, a psychological approach or cognitive appraisal tends to be used based on Lazarus and his friends' thinking. They introduced the cognitive theory in studying the phenomenon of stress.

Based on this psychological approach, the concept of work stress includes five components of analysis, namely: 1) work situations or sources of work stress that are potential to stress, 2) cognitive assessment, which includes primary assessment and secondary assessment of sources of stress, 3) individual differences, in the form of personal characteristics and environmental characteristics that affect cognitive assessment, 4) job stress responses experienced by individuals, and 5) due to stress that is psychological, physiological, and behavioural. Based on the reference to the cognitive assessment approach, work stress in this paper is formulated as a psychological condition experienced by individuals as a reaction to the results of their assessment of work situations that threaten their well-being and are felt unsatisfactory.

Based on these two functions, several authors have proposed various stress management techniques. Luthans (1989) divides stress management strategies into two, namely organizational processes and individual design. Research on stress management strategies among educators is still minimal. Several studies have been conducted showing the tendency to use unique techniques in dealing with stress. Research conducted by Okebukola and Jegede (1992) revealed the five strategies most often used by teachers, namely: (1) positive thinking, (2) making improvisational efforts, (3) always cheerful, (4) sharing ideas and tools. Laboratory among teachers, and (5) being relaxed.

These studies have not categorized stress management strategies based on focus: feelings and problems. Therefore, Gaziel's (1993) study classifies stress management strategies into four groups that need to be developed in stress management studies for teachers and school principals. The four strategies are as follows, namely: 1) active behavioural strategies, 2) active cognitive strategies, (3) inactive behavioural strategies, and inactive cognitive strategies.

Several sources of research data used in searching and collecting literature are Google Scholar, Scopus, Web of Science, ScienceDirect, and ERIC. The authors' findings summarise the research that revolves around work stress, work stress, and job stress.

Civil servants are under more job pressure than private teachers in India (Doss, Rachel, Jarrar, AbuMadini, \& Sakthivel, 2018). Most Jordanian teachers experience work-related stress. Poor working conditions were the highest cause of job stress among Jordanian teachers, followed by: (1) personal factors, (2) work, (3) lack of support, and (4) student factors (Almahsneh, 2020; Dankade, Bello, \& Deba, 2016). Job stress is negatively associated with job satisfaction for North American teachers (Canada \& US). Collectivism culture is significantly related to Korean teacher job satisfaction but not North American teachers (Klassen et al., 2010; Klassen \& Chiu, 2011). Valid 
predictors of stress, burnout, and job dissatisfaction in teachers are (1) co-worker support, (2) optimism, (3) hardiness, (4) daily hassles, and (5) life events (Lopez, Bolano, \& Marino, 2010; D. Wu, 2020; Liu \& Onwuegbuzie, 2012).

Findings suggest that organizational climate and teacher involvement as potential drivers for change support previous work on teacher stress and school satisfaction (Ouellette, Frazier, Shernoff, Cappella, Mehta, Maríñez-Lora, Cua, \& Atkins, 2018). Most principals are satisfied but feel pressured by their work, and age, type of school, experience, position, and practice have varying effects on job stress and job satisfaction (Bedi, Kukemelk, \& Bardone, 2021). Measurement models that describe the factors that contribute to primary school teacher work stress include (1) student delinquency, (2) workload, (3) professional recognition, (4) time and resources, (5) interpersonal relationships, (6) training and technology support, (7) curriculum facilities and constraints on their presentation, and (8) technological literacy (Abdullah \& Ismail, 2019).

Based on the above background, this research's problem is how the phenomenon of teacher work stress in South Sulawesi today, especially when it is related to the impact of regional autonomy policies in the field of education.

This research was conducted in Indonesia, which in the last 20 years has experienced many policy changes in the education sector. Changes in education policy are mainly related to granting autonomy and decision-making authority to district governments in managing education in the regions. Changes in decision-making patterns are thought to affect teachers' work environment, which has implications for the source of their work stress. Based on the above study and new policies in education, this study aims to describe the current phenomenon of teacher work stress in South Sulawesi. The research questions are: 1) What is the description of the levels of teacher work stress in South Sulawesi? 2) What is the description of the sources of teacher work stress in South Sulawesi?

\section{METHOD}

The research uses a quantitative descriptive design by distributing questionnaires to teachers in South Sulawesi. This stage is the first stage to identify the levels and sources of teacher's work stress.

Sampling was carried out by using multi-stage cluster random sampling with the following procedures:

1. The first step for the population of 24 districts/cities, the sample was determined purposively, namely three districts/cities, namely Makassar City, Sinjai district, and Pangkajene Islands district.

2. Based on the consideration of all levels of education's homogeneity. It was decided that only SMA \& SMK teachers from the three districts were sampled: Makassar High School \& Vocational High School Teachers with a total population of 3,331, SMA \& SMK Kab. Pangkajene Islands with a total population of 946, and teachers of SMA \& SMK Kab. Sinjai with a population of 777 (The data source is the result of research data processing).

3. The sample of research subjects was then taken by proportional random sampling from the three districts/cities, with a sample size of 357 obtained from the Krejcie's Table. The sample distribution is as in Table 1.

Table 1. Research Sample

\begin{tabular}{cllc}
\hline No & District/City & Calculation & Sample \\
\hline 1 & Makassar city & $(3331 \times 357) / 5054$ & 235 \\
\hline 2 & Pangkajene Kepulauan & $(946 \times 357) / 5054$ & 67 \\
\hline 3 & Sinjai & $(777 \times 357) / 5054$ & 55 \\
\hline \multicolumn{2}{c}{ TOTAL } & & 357 \\
\hline
\end{tabular}

Copyright () 2022, author, e-ISSN 2442-8620, p-ISSN 0216-1370 


\section{Instrument and Procedures of Data collection}

The questionnaire consists of 38 items to find out how stressful a particular situation is. Respondents' answers shifted from not stressed to very stressed. The unstressing score was one, and the most pressing was 5 .

The construct validity was performed using factor analysis techniques. Based on the factor analysis, There were 38 items resulted in six subscales: 1) welfare; 2) teaching; 3) students; 4) relationships and conflicts; 5) organizational climate; and 6) the time dimension. These six factors have a variant of 72.7 percent, which is considered adequate to represent the 45 questionnaires. The largest number of variants contributed by factor 1 was 44.3 percent, factor 2 was 8.4 percent, factor 3 was 5.6 percent, factor 4 was 4.3 percent, factor 5 was 3.8 percent, factor 6 was 3.3 percent, and a factor of 7 in the amount of 2.9 percent, furthermore, from the 38 question items.

The respondent's answers were anchored on a 1 to five Likert-like scale from never to very often, see the attached questionnaire. A reliability test was conducted to determine the internal consistency of the questionnaire. The validity and reliability of the questionnaire were analyzed using SPSS 23 software. Factor analysis on sources of work stress was analyzed using SPSS 23 software.

Table 2. Validity of Stress Source Indicator

\begin{tabular}{lllll}
\hline Indicator & average $\mathrm{r}$ & $\mathrm{r}$ table & $P$-value & Category \\
\hline Welfare & 0.6048 & 0.576 & 0.000 & Valid \\
Teaching & 0.6518 & 0.576 & 0.000 & Valid \\
Student & 0.775 & 0.754 & 0.000 & Valid \\
Relationships and conflict & 0.737 & 0.632 & 0.000 & Valid \\
Organizational climate & 0.708 & 0.602 & 0.000 & Valid \\
Time & 0.893 & 0.878 & 0.000 & Valid \\
\hline
\end{tabular}

Table 2 shows that each indicator for validity testing is valid. This valid value immediately occurs on the first test. The average value of the $r$ count is greater than the $r$ table. The P-value is smaller than 0.05 .

Table 3. Reliability of Stress Source Indicators

\begin{tabular}{lll}
\hline Indicator & Cronbach's Alpha & N of Items \\
\hline Stress source & 0.953 & 45 \\
\hline
\end{tabular}

Table 3 shows the reliability of the source indicator as a whole has a Cronbach value of 0.953 . The value of the $\mathrm{r}$ table at the $5 \%$ significance level at the value of $\mathrm{N}=45 \mathrm{is} 0.294$. The value of 0.953 is more significant than 0.294 , so that it can be concluded that it is reliable as a data collection tool in research.

\section{Data Analysis}


Descriptive analysis techniques are used to process data obtained through a questionnaire in a descriptive percentage. The formula used to calculate the percentage of each subject is:

Percentage $=\sum$ (answer $\mathrm{x}$ the score of each choice) $\times 100 \%$

$\mathrm{n} \times$ the highest score

Information: $\sum=$ amount dan $\mathrm{n}=$ the total number of questionnaire items

Furthermore, to calculate the percentage of all subjects used the formula:

Percentage $=\mathrm{F}: \mathrm{N}$

Information: $\mathrm{F}=$ the total percentage of subjects.

$\mathrm{N}=$ number of subjects.

Descriptive analysis uses the percentage formula as follows.

$\mathrm{P}=\mathrm{n} / \mathrm{N} \times 100 \%$

Information : $\mathrm{P}=$ Percentage

$\mathrm{n}=$ Score

$\mathrm{N}=$ Total score

Table 4. Score of stress sources data

\begin{tabular}{cc}
\hline Interval & Category \\
\hline $189<\mathrm{x} \leq 225$ & Very High \\
$153<\mathrm{x} \leq 189$ & High \\
$117<\mathrm{x} \leq 153$ & Moderate \\
$81<\mathrm{x} \leq 117$ & Low \\
$45<\mathrm{x} \leq 81$ & Very Low \\
\hline
\end{tabular}

The teacher work stress variable consists of six sub-variables/indicators, namely (1) welfare, (2) teaching, (3) students, (4) relationship \& conflict, (5) organizational climate, (6) time, with 45 items of statements on a scale 1 to 5 , thus the score is in the range $45<x<225$ with the highest possible score being $(45 \times 5=225)$ and the lowest possible score is $(45 \times 1=45)$. The description of this variable uses five categories, namely very pressing, pressing, slightly pressing, not pressing, and not pressing at all, so that in this case. The number of class intervals is also five. The class length can be found by dividing the range (maximum score-minimum score) $i=225-45=180$; with the number of categories namely 5 , so it is found that the class length of the interval $c=180 / 5=36$.

The CVR (content validity ratio) proposed by Lawshe (1975) is a linear transformation of the proportional level of agreement on how many validators in the panel rated "essential" items calculated in the following way:

$$
\mathrm{CVR}=\underline{\mathrm{n}}_{\mathrm{e}} \frac{-(\mathrm{N} / 2)}{\mathrm{N} / 2}
$$

where CVR is the content validity ratio, $n_{e}$ is the number of panel members indicating an item "essential," and $\mathrm{N}$ is the number of panel members (Ayre \& Scally, 2014).

Content validity analysis using the Aiken coefficient was used to test the validity of the observation sheet (Azwar, 2012; Aiken, 1985), with content validity introduced by Lawshe (1975), used to test the content validity of the test instrument.

The data were analyzed to determine KMO and Bartlett's test, Anti-image Matrices, Communalities, Total variance explained and Component matrix. All of this will be interpreted in the research results (Hadia, Abdullah, \& Sentosa, 2016). 
FINDING AND DISCUSSION

Finding

Aiken Content Validity Analysis and Content Validity Ratio (CVR)

The results of the analysis can be categorized as valid if they meet the V Aiken coefficient limit. The boundary conditions for the $\mathrm{V}$ Aiken coefficient for 5 rating scales and seven raters are 0.75 with a probability of 0.41 .

Table 5. Average V Aiken scores of work stress source indicators

\begin{tabular}{ll}
\hline Indicator & Average of V Aiken \\
\hline Welfare & 0.88 \\
Teaching & 0.88 \\
Student & 0.84 \\
Relationships and conflict & 0.89 \\
Organizational climate & 0.88 \\
\hline
\end{tabular}

Each source of work stress indicator gets the average V Aiken coefficient in table 5 is more significant than 0.75 . Thus, all of these indicators are declared valid so that they are suitable for use in experiments. The CVR value must meet 0.99 so that the item can be declared valid. This applies to content validation using 7 SMEs (Lawshe, 1975). The CVR value obtained for each item is one and is fully presented in the appendix. The CVI value obtained from the average CVR is 1 . Based on the CVR value that exceeds 0.99, all items are declared valid (Lawshe, 1975) and are suitable for further research.

\section{Description of Level of Teacher Work Stress}

The summary of the results of the analysis of descriptions of stress-sources variables for teachers in South Sulawesi can be seen in Table 6.

Table 6. Distribution of stress sources data for teachers in South Sulawesi

\begin{tabular}{cccc}
\hline Interval & $\mathrm{F}$ & $\%$ & Category \\
\hline $189<\mathrm{x} \leq 225$ & 5 & 1.4 & Very High \\
$153<\mathrm{x} \leq 189$ & 119 & 33.33 & High \\
$117<\mathrm{x} \leq 153$ & 157 & 43.97 & Moderate \\
$81<\mathrm{x} \leq 117$ & 76 & 21.3 & Low \\
$45<\mathrm{x} \leq 81$ & 0 & 0.0 & Very Low \\
\hline
\end{tabular}

The average stress source variable data is $41.9 \%$ which is in the range of $117<\mathrm{x} 153$ with moderate stress category. So it can be concluded that the source of teacher work stress in South Sulawesi experienced by teachers is somewhat stressful.

\section{Description of Source of Teacher Work Stress}


Below will be analyzed the sources of stress based on the six main factors of teacher work stress instruments.

Welfare and Teaching

The welfare indicator as a source for teacher work stress has 10 statement items on a scale of 1 to 5 . Thus the score is in the range of $10<x<50$, with the highest possible score is $(10 \times 5=50)$ and the lowest possible score is $(10 \times 1=10)$. The interval is (maximum score-minimum score) $\mathrm{i}=50-10=$ 40 , with an interval class length of $c=40 / 5=8$. For more details, a description of the welfare sub variable's data as a stressor for teachers in South Sulawesi can be seen in Table 7.

Table 7. Data distribution on Welfare and Teching Indicators as a source for Teacher Work Stress

\begin{tabular}{llllll}
\hline \multirow{2}{*}{ Interval } & $\mathrm{F}$ & \multicolumn{5}{c}{$\%$} & Category \\
\cline { 2 - 5 } & Welfare & Teaching & Welfare & Teaching & \\
\hline $42<\mathrm{x} \leq 50$ & 25 & 17 & 7 & 4.76 & Very High \\
$34<\mathrm{x} \leq 42$ & 123 & 109 & 34.45 & 30.53 & High \\
$26<\mathrm{x} \leq 34$ & 118 & 153 & 33.05 & 42.86 & Moderate \\
$18<\mathrm{x} \leq 26$ & 79 & 74 & 22.13 & 20.73 & Low \\
$10<\mathrm{x} \leq 18$ & 12 & 4 & 3.36 & 1.12 & Very Low \\
\hline
\end{tabular}

The average stress source variable data was 31.87 , which was in the range $26<x \leq 34$ with a rather stressful category. So it could be concluded that teacher welfare as a source for teacher work stress in South Sulawesi experienced by teachers was somewhat stressful.

The average stress source variable data was 31.68 , which was $26<\mathrm{x} \leq 34$ with a rather stressful category. So it can be concluded that teacher teaching as a Source for teacher work stress in South Sulawesi experienced by teachers is in the somewhat stressful category.

\section{Student}

Student indicators as a source for teacher work stress have five items of statements on a scale of 1 to 5 . Thus the score is in the range of $5<x<25$ with the highest possible score is $(5 \times 5=25)$ and the lowest possible score is $(5 \times 1=5)$. The interval is (maximum score-minimum score) $\mathrm{i}=25-5=$ 20 , the length of the interval class is $\mathrm{c}=20 / 5=4$. For more details, a description of the student subvariable data as a stressor for teachers in South Sulawesi can be seen in Table 8 .

Table 8. Data Distribution on Student Indicators as a source for Teacher Work Stress

\begin{tabular}{cccc}
\hline Interval & $\mathrm{F}$ & $\%$ & Category \\
\hline $21<\mathrm{x} \leq 25$ & 23 & 6.44 & Very High \\
$17<\mathrm{x} \leq 21$ & 100 & 28 & High \\
$13<\mathrm{x} \leq 17$ & 136 & 38.1 & Moderate \\
$9<\mathrm{x} \leq 13$ & 91 & 25.5 & Low \\
$5<\mathrm{x} \leq 9$ & 7 & 1.96 & Very Low \\
\hline
\end{tabular}

The average stress source variable data was 15.83 , which was in the range $13<x \leq 17$, with a rather stressful category. It can be concluded that students as sources for teacher work stress in South Sulawesi experienced by teachers are in the somewhat stressful category.

\section{Relationships and Conflict}

Copyright (C) 2022, author, e-ISSN 2442-8620, p-ISSN 0216-1370 
Indicators of relationship and conflict as source for teacher work stress have eight items with a scale of 1 to 5 . Thus the score is in the range of $8<x<25$ with the highest possible score $(8 \times 5=$ $40)$ and the possible score. the lowest is $(8 \times 1=8)$. The interval is (maximum score-minimum score) $\mathrm{i}=40-8=32$, the length of the interval class $\mathrm{c}=32 / 5=6.4$. For more details, the data description of the relationship and conflict sub-variables as stress source for teachers in South Sulawesi can be seen in Table 9.

Table 9. Data distribution on Relationship and Conflict Indicators as a source for Work Stress

\begin{tabular}{cccc}
\hline Interval & $\mathrm{F}$ & $\%$ & Category \\
\hline $33,6<\mathrm{x} \leq 40$ & 24 & 6.7 & Very High \\
$27,2<\mathrm{x} \leq 33,6$ & 78 & 21.9 & High \\
$20,8<\mathrm{x} \leq 27,2$ & 130 & 36.4 & Moderate \\
$14,4<\mathrm{x} \leq 20,8$ & 100 & 28.0 & Low \\
$8<\mathrm{x} \leq 14,4$ & 25 & 7.0 & Very Low \\
\hline
\end{tabular}

The average stress-source variable data was 23.90 in the range of $20.8<\mathrm{x} \leq 27.2$ with a rather stressful category. It can be concluded that teacher relationships and conflicts as sources for teacher work stress in South Sulawesi experienced by teachers are in the somewhat oppressive category.

\section{Organizational Climate}

The indicator of organizational climate as a source for teacher work stress has nine items on a scale of 1 to 5 . Thus the score is 9 - 45 with the highest possible score $(9 \times 5=45)$, and the lowest possible score is ( $9 \times 1=9$ ). The interval is (maximum score-minimum score) $i=45-9=36$, the length of the interval class is $c=36 / 5=7.2$. For more details, the data description of the organizational climate sub-variable as a stressor for teachers in South Sulawesi can be seen in Table 10.

Table 10. Data Distribution on Organizational Climate Indicators as a source for Teacher Work Stress

\begin{tabular}{crrc}
\hline Interval & $\mathrm{F}$ & $\%$ & Category \\
\hline $37,8<\mathrm{x} \leq 45$ & & & \\
$30,6<\mathrm{x} \leq 37,8$ & 1 & 0.3 & Very High \\
$23,4<\mathrm{x} \leq 30,6$ & 45 & 12.6 & High \\
$16,2<\mathrm{x} \leq 23,4$ & 168 & 47.1 & Moderate \\
$9<\mathrm{x} \leq 16,2$ & 113 & 31.6 & Low \\
\hline
\end{tabular}

The average stress Sources variable data was 24.82, which was in the range $23.4<x \leq 30.6$ with the Slightly Depressing category. So that it could be concluded that the teacher organizational climate as a Sources for teacher work stress in South Sulawesi experienced by teachers was category is a bit oppressive.

\section{Time}

The time indicator as a source for teacher work stress has three items of statements on a scale of 1 to 5 . Thus the score is in the range of $15-3$, with the highest possible score is $(3 \times 5=15)$ and the lowest possible score is $(3 \times 1=3)$. The interval is (maximum score-minimum score) $15-3=12$, the length of the interval class is $12 / 5=2.4$. To find out the interval class and frequency of each class can be seen in Table 11. 
Table 11. Data Distribution on Time Indicators as a source for Teacher Work Stress

\begin{tabular}{llll}
\hline Interval & $\mathrm{F}$ & $\%$ & Category \\
\hline $12,6<\mathrm{x} \leq 15$ & 10 & 2.8 & Very High \\
$10,2<\mathrm{x} \leq 12,6$ & 85 & 23.8 & High \\
$7,8<\mathrm{x} \leq 10,2$ & 115 & 32.2 & Moderate \\
$5,4<\mathrm{x} \leq 7,8$ & 135 & 37.8 & Low \\
$3<\mathrm{x} \leq 5,4$ & 12 & 3.4 & Very Low \\
\hline
\end{tabular}

The average stress source variable data was 8.89 , which was in the range of $5.4<\mathrm{x} \leq 7.8$ with a rather stressful category. It can be concluded that teacher time as a source for teacher work stress in South Sulawesi experienced by teachers is in the category rather pressing.

\section{Factor Analysis of the Sources of Work Stress}

Table 12. KMO and Bartlett's Test

\begin{tabular}{llr}
\hline \multicolumn{2}{l}{ Kaiser-Meyer-Olkin Measure of Sampling } & .866 \\
\hline Bdequacy. & Approx. Chi-Square & 1266.237 \\
Sphericity & df & 15 \\
& Sig. & .000 \\
\hline
\end{tabular}

Table 12 is the output table of KMO and Bartlett's test to determine the feasibility of a variable that can be further processed using factor analysis techniques. The rule is to look at the KMO MSA (Kaiser-Meyer-Olkin Measure of Sampling Adequacy) value. If the KMO MSA value is more significant than 0.50 , then the factor analysis technique can be continued. Based on the output in table 10 , the KMO MSA value is $0.866>0.50$. The value of Bartlett's Test of Sphericity (Sig.) $0.000<$ 0.05 . Thus the factor analysis in the research can be continued because it meets the requirements.

a. Measures of Sampling Adequacy (MSA)

In table 14, Anti-image aims to determine the appropriate variables to be used in factor analysis. Table 14 shows the letter code (a), a sign for Measure of Sampling Adequacy (MSA). The MSA values of each variable are: 1) Welfare 0.857 ; 2) Teaching 0858; 3) Students 0.955 ; 4) Relationships and conflicts $0.849 ; 5$ ) Organizational Climate $0.820 ; 6$ ) Time 0.922 . The MSA value of each variable is greater than 0.50 . Thus the second requirement (MSA) is met in the factor analysis. 
Table 13. Anti-image Matrices

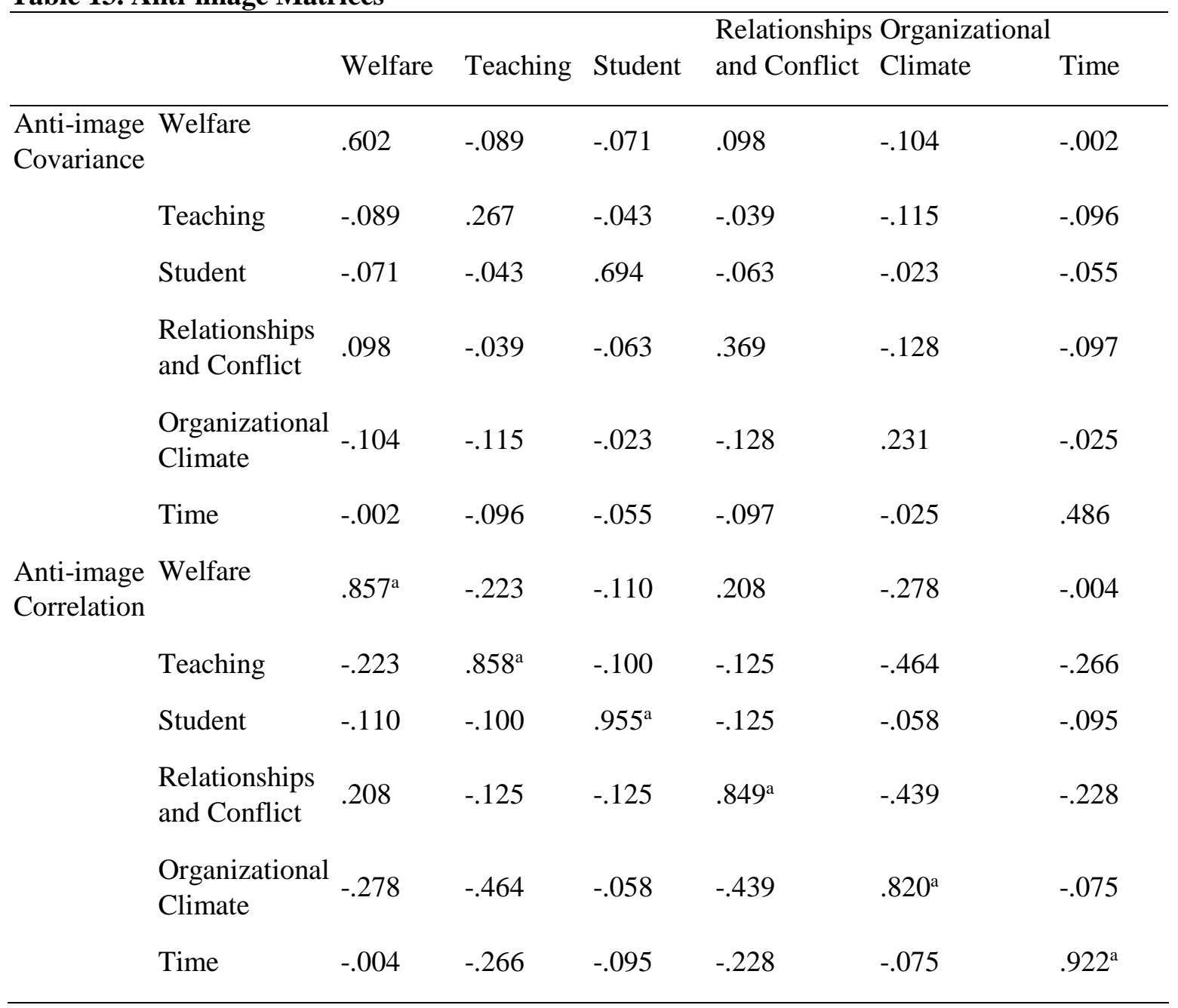

Table 13. Communalities Variabel

\begin{tabular}{lll}
\hline & Initial & Extraction \\
\hline Welfare & 1.000 & .446 \\
Teaching & 1.000 & .815 \\
Student & 1.000 & .445 \\
Relationships and Conflict & 1.000 & .686 \\
Organizational Climate & 1.000 & .831 \\
Time & 1.000 & .635 \\
\hline
\end{tabular}

Extraction Method: Principal Component Analysis.

Table 14, Communalities shows the value of the variables studied whether they can explain the factor or not. Variables are considered capable of explaining the factor if the Extraction value is greater than 0.05. Based on table 12, the Welfare variable and the Student variable cannot explain the factor because the value is less than 0.5 . There are four variables whose value is greater than 0.5 , 
namely: variable teaching, relationships and conflict, organizational climate, time. Thus the four variables can be used to explain the factors.

Table 14. Total Variance Explained

\begin{tabular}{crrrrrr}
\hline & \multicolumn{3}{c}{ Initial Eigenvalues } & \multicolumn{3}{c}{ Extraction Sums of Squared Loadings } \\
Component & \multicolumn{1}{c}{ Total } & \% of Variance & Cumulative \% & Total & \% of Variance & ve \% \\
\hline 1 & 3.857 & 64.287 & 64.287 & 3.857 & 64.287 & 64.287 \\
2 & .699 & 11.657 & 75.944 & & & \\
3 & .628 & 10.460 & 86.404 & & & \\
4 & .400 & 6.660 & 93.064 & & \\
5 & .256 & 4.270 & 97.334 & & \\
6 & .160 & 2.666 & 100.000 & & & \\
\hline
\end{tabular}

Extraction Method: Principal Component Analysis.

Table 14 shows that the eigenvalue of component 1 is 3.857, which is greater than 1 and can explain $64.287 \%$ of the variation. Thus component 1 qualifies as a factor. Components 2 to 6 cannot be a factor because the total value is less than 1 .

Table 15. Component Matrix ${ }^{\mathrm{a}}$

\begin{tabular}{lc}
\hline & Component 1 \\
\hline Welfare & .668 \\
Teaching & .903 \\
Student & .667 \\
Relationships and Conflict & .828 \\
Organizational Climate & .912 \\
Time & .797 \\
Extraction Method: Principal Component Analysis.
\end{tabular}

a. 1 components extracted.

Table 15 shows only one component. There is no rotated Component Matrix and Component Transformation Matrix. The correlation value in component 1 shows a value greater than 0.5 . The conclusion is that the factors formed can summarize the five variables analyzed. Thus the five indicators can be used to develop sources of work stress.

\section{DISCUSSION}

\section{Level of Teachers Work Stress}

The results of this study indicate that as many as $43.97 \%$ of teachers experience moderate stress. This study's results are not much different from previous studies' findings, such as those conducted by Borg dan Riding (1993) and Fontana dan Abouserie (1993), which revealed that the majority of teachers in their study experienced moderate work stress. The fact that most teachers are under moderate stress is not a cause for concern. According to Davis dan Newstrom (1993), work stress can increase individual performance at an average level.

What is worrying is the research findings that show a large percentage of teachers who experience severe work stress (high and very high). This study revealed that as many as $34.73 \%$ of teachers experienced extreme work stress (high and very high). Research by Borg dan Riding (1993) found

$$
\text { Copyright (C) 2022, author, e-ISSN 2442-8620, p-ISSN 0216-1370 }
$$


that $16.5 \%$ of teachers experienced high work stress. Fontana dan Abouserie (1993), a study on a sample of primary and secondary school teachers, found that $23.2 \%$ of teachers experienced severe work stress. Even surprisingly, this study shows that the percentage of teachers who experience extreme work stress is higher, namely $34.73 \%$, compared to the previous author,s research in the same region, which only found that the percentage of teachers who experienced serious work stress was $30.27 \%$ (Arismunandar, 1997).

The high percentage of teachers who experience severe stress is caused by various factors, especially changes in regional autonomy policies in education. This policy causes the intensity of supervision by officials and supervisors in the regions to increase teacher performance. Not to mention the increasing demands of parents and society for improving teacher performance.

\section{Sources of Teacher Work Stress}

Based on the results of this study in more detail, it is known that the dominant or general source of teacher work stress comes from the welfare factor and the teaching factor, each of which consists of four items of the highest source of work stress. Meanwhile, other teacher work stress factors originate from student factors and organizational climate, consisting of one source of job stress. Thus, it can be concluded that the need for stress management that needs to be given successive treatment is welfare, teaching, students, and organizational climate. This fact has practical implications for the need for strategies and efforts to deal with teacher work stress. These strategies and efforts are known as stress management.

From forty-five items on the teacher work stress variable found six common/dominant stressor for teacher work stress. The six work stressors according to their ranking are: 1) changing curriculum demands; 2) convoluted promotion/position procedures; 3 ) too heavy teaching load; 4) individual students who frequently misbehave continuously; 5) too much administrative/writing work; and 6) inadequate facilities and teaching resources. The results of this study are different from those of Arismunandar (1997) which previously found six dominant sources of teacher work stress in South Sulawesi, namely: 1) salary deductions; 2) pending promotions; 3) individual students who consistently misbehave; 4) conflicts with other personnel; 5) the school environment is too noisy; and 6) lack of motivation, attention, and student response to lessons. Unlike previous studies, this study found new dominant job stress sources: 1) demands curriculum changes; 2) excessive workload; 3 ) too many administrative tasks; and 4) inadequate facilities and learning resources. These four dominant sources of stress indicate the increasing demand for teacher work due to policy changes in education.

Based on the research findings, especially regarding the increasing stress levels of teachers and the existence of dominant sources of teacher work stress, stress management strategies are needed to help teachers overcome the problems they face in the work environment.

Stress management strategies as forms of stress management have two essential functions: reducing the stress that is too stressful and keeping the pressure at a level that can improve performance. The first function can be seen from the work stress model mentioned above. Stress management is essential in assisting the individual in making secondary assessments. If the individual feels unable to deal with stress sources in the second assessment, stress management can help the individual offer strategies to deal with stress. Thus, if individuals are equipped with various stresscoping techniques, personal stress will be reduced.

Based on these two functions, several authors have proposed various stress management techniques. Luthans (1995) divides stress management strategies into two, namely organizational processes and individual strategies. Research on stress management strategies among educators is still minimal. Several studies have been conducted showing the tendency to use personal strategies in dealing with stress. Research conducted by Okebukola \& Jegede (1992) revealed the five strategies 
most often used by teachers, namely: 1) positive thinking; 2) making improvisational efforts; 3 ) always cheerful; 4) sharing ideas and laboratory equipment among teachers; and 5) being relaxed.

Allison (1997) examined stress management among school principals. He founded ten management strategies that were most frequently used, namely: 1) applying good human relations skills with staff; 2) always being humorous; 3) approaching problems objectively and optimistic; 4) sleep regularly; 5) set realistic goals; 6) delegate responsibilities; 7) discuss issues with family members and closest relatives; 8) engage in hobby activities such as fishing, camping, playing tennis, etc.; 9) engaging in leisure activities such as watching, attending music concerts, eating outside the home, etc.; and (10) working hard including evenings and weekends. Antoniou, Ploumpi, \& Ntalla (2013), similar findings indicate strategies commonly used by teachers, such as avoiding problems, asking for help from others, and doing fun activities.

Based on this, teachers need to have a systematic pattern, especially using a cognitive approach in dealing with their work stress. It is considered a vital effort to improve teacher competence, especially in developing work stress management strategies to overcome work stress sources and their consequences. One of the efforts that need to be done for that is through training. Training is a form of effective group intervention in dealing with teacher work stress (Shimazu, Okada, Sakamoto, \& Miura, 2003). According to Robbins, (1998), this mechanism occurs because having friends, family, or co-workers to talk to provides an outlet when stress levels are excessive. In the context of the principal's research, it shows that there is a significant relationship between in-service training and empowerment of high school principals (Chenari, Sohrabimanesh, \& Heydari, 2016). Research on the school-based management training model also shows the positive effect of exercise in increasing the competence of school principals (Arismunandar, Nurhikmah \& Achmad, 2016).

Teachers can increase their self-control and work involvement to reduce work stress (Li, Leung, $\& \mathrm{Li}, 2021)$. Teachers who participate in stress management programs can reduce teacher burnout and know how to reduce stress (Ansley, Houchins, Varjas, Roach, Patterson, \& Hendrick, 2021). Instructors apply more problem-focused and less emotion-focused strategies. Thus they experience less emotional exhaustion. They offer students more opportunities to choose and increase the relevance of learning. Coping strategies mediate the relationship between stressors and emotional exhaustion so that teachers care about their students and with less workload. Thus teachers experience less burnout because these teachers use problem-focused strategies more often and use emotionfocused strategies less frequently (Pogere et al., 2019).

\section{CONCLUSIONS}

Factor analysis shows that all variables can be used in the study. Based on the results of this study, it is known that the level of teacher work stress in South Sulawesi experienced by teachers is in the medium category with a data trend of $41.9 \%$. Teacher work stress in the low category is $20.3 \%$, and teacher work stress is in the high category of $1.3 \%$. The work stress category is based on six factors/sources for work stress, namely (1) Welfare; (2) teaching; (3) students; (4) relationships and conflicts; (5) organizational climate; and (6) the time dimension with the dominant or general source of teacher work stress originating from welfare and teaching factors, while other teacher work stress factors that also Sources work stress are student factors and organizational climate. This fact has practical implications for stress management training for teachers in South Sulawesi to deal with teacher work stress. 


\section{REFERENCES}

Abdullah, A. S., \& Ismail, S. N. (2019). A Structural Equation Model Describes Factors Contributing Teachers' Job Stress in Primary Schools. International Journal of Instruction, 12(1), 1251-1262. https://doi.org/10.29333/iji.2019.12180a.

Aiken, L. R. (1985). Three Coefficients for Analyzing the Reliability and Validity of Ratings. Educational and Psychological Measurement, 45(1), 131-142. https://doi.org/10.1177/00131644854 51012.

Allison, D. G. (1997). Coping with stress in the principalship. Journal of Educational Administration, 35(1), 39-55. https://doi.org/10.1108/09578239710156971.

Almahsneh, K. salem ali. (2020). Occupational Stress Among School Teachers In Jordan. International Journal of Advanced Science and Technology, 29(7), 5679-5686.

Anandasayanan, S., \& Subramaniam. (2013). Effect of Stress on Teachers' Performance with Special Reference to Jaffna District Schools (SSRN Scholarly Paper ID 2386067). Social Science Research Network. https://doi.org/10.2139/ssrn.2386067.

Ansley, B. M., Houchins, D. E., Varjas, K., Roach, A., Patterson, D., \& Hendrick, R. (2021). The impact of an online stress intervention on burnout and teacher efficacy. Teaching and Teacher Education, 98, 103251. https://doi.org/10.1016/j.tate.2020.103251.

Antoniou, A.-S., Ploumpi, A., \& Ntalla, M. (2013). Occupational stress and professional burnout in teachers of primary and secondary education: The role of coping strategies. Psychology, 4(03), 349-55.

Ayre, C., \& Scally Andrew J. (2014). Critical Values for Lawshe's Content Validity Ratio: Revisiting the Original Methods of Calculation. Measurement and Evaluation in Counseling and Development, 47(1), 79-86. https://doi.org/10.1177/0748175613513808.

Azwar, S. (2012). Reliabiltas dan validitas (4th ed.). Yogyakarta: Pustaka Pelajar.

Bedi, I. K., Kukemelk, H., \& Bardone, E. (2021). Practices, Personal and School Factors that Influenced School Heads' Job Stress and Satisfaction. European Journal of Educational Research, 10(1), 51-62. https://doi.org/10.12973/EU-JER.10.1.51.

Bottiani, J. H., Duran, C. A. K., Pas, E. T., \& Bradshaw, C. P. (2019). Teacher stress and burnout in urban middle schools: Associations with job demands, resources, and effective classroom practices. Journal of School Psychology, 77, 36-51. https://doi.org/10.1016/j.jsp.2019.10.002.

Burman, R., \& Goswami, T. G. (2018). A Systematic Literature Review of Work Stress. International Journal of Management 112. https://doi.org/10.18843/ijms/v5i3(9)/15. 
Chaplain, R. P. (2006). Stress and Job Satisfaction: A study of English primary school teachers. Educational Psychology, 15(4), 473-489. https://doi.org/10.1080/0144341950150409.

Chenari, A., Sohrabimanesh, M., \& Heydari, S. (2016). Studying the Effect of In-Service Training on Empowerment of School Principals (Case study: Public high school principals in Tehran). Journal of Current Research in Science, 2, 735.

Dankade, U., Bello, H., \& Deba, A. (2016). Analysis of Job Stress Affecting the Performance of Secondary Schools' Vocational Technical Teachers in North East, Nigeria. Journal of Technical Education and Training, 8(1), 43-51.

Doss, C. A. V., Rachel, J. J., Jarrar, M. K., AbuMadini, M. S., \& Sakthivel, M. (2018). A Comparative Study to Determine the Occupational Stress Level and Professional Burnout in Special School Teachers Working in Private and Government Schools. Global Journal of Health Science, 10(3), 42. https://doi.org/10.5539/gjhs.v10n3p42.

Hadia, N. U., Abdullah, N., \& Sentosa, I. (2016). An Easy Approach to Exploratory Factor Analysis: Marketing Perspective. Journal of Educational and Social Research, 6(1), 215-223. https://doi.org/10.5901/jesr.2016.v6n1p215.

Herman, K. C., Prewett, S. L., Eddy, C. L., Savala, A., \& Reinke, W. M. (2020). Profiles of middle school teacher stress and coping: Concurrent and prospective correlates. Journal of School Psychology, 78, 54-68. https://doi.org/10.1016/j.jsp.2019.11.003.

Ismail, S. N., Abdullah, A. S., \& Abdullah, A. G. K. (2019). The Effect of School Leaders' Authentic Leadership on Teachers' Job Stress in the Eastern Part of Peninsular Malaysia. International Journal of Instruction, 12(2), 67-80. https://doi.org/10.29333/iji.2019.1225a.

Junker, R., Donker, M. H., \& Mainhard, T. (2021). Potential classroom stressors of teachers: An audiovisual and physiological approach. Learning and Instruction, 75, 101495. https://doi.org/10.1016/j.learninstruc.2021.101495.

Klassen, R. M., \& Chiu, M. M. (2011). The Occupational Commitment and Intention to Quit of Practicing and Pre-service Teachers: Influence of Self-efficacy, Job Stress, and Teaching Context. $\begin{array}{llll}\text { Contemporary } \quad \text { Educational } & \text { Psychology, } & 36, & 129 .\end{array}$ https://doi.org/10.1016/j.cedpsych.2011.01.002.

Klassen, R. M., Usher, E. L., \& Bong, M. (2010). Teachers' collective Efficacy, Job Satisfaction, and Job Stress in Cross-cultural Context. The Journal of Experimental Education, 78(4), 464-486. https://doi.org/10.1080/00220970903292975.

Lawshe, C. H. (1975). A quantitative approach to content validity. Personnel Psychology, 28(4), 563-575. https://doi.org/10.1111/j.1744- 6570.1975.tb01393.x.

Li, J.-B., Leung, I. T. Y., \& Li, Z. (2021). The pathways from self-control at school to performance at work among novice kindergarten teachers: The mediation of work engagement and work stress. Children and Youth Services Review, 121, 105881. https://doi.org/10.1016/j.childyouth.2020.105881. 
Liu, S., \& Onwuegbuzie, A. J. (2012). Chinese Teachers' Work Stress and Their Turnover Intention. International Journal of Educational Research, 53, 160-170. https://doi.org/10.1016/j.ijer.2012.03.006.

Lopez, J. M. O., Bolano, C. C., \& Marino, M. J. S. (2010). Exploring Stress, Burnout, and Job Dissatisfaction in Secondary School Teachers. International Journal of Psychology and Psychological Therapy, 10(1), 107-123.

Luthans, F. (1995). Organizational Behavior, international edition. İstanbul: Literatür Yayıncılık.

Mo, Y., Deng, L., Zhang, L., Lang, Q., Liao, C., Wang, N., Qin, M., \& Huang, H. (2020). Work stress among Chinese nurses to support Wuhan in fighting against COVID-19 epidemic. Journal of Nursing Management, 28(5), 1002-1009. https://doi.org/10.1111/jonm.13014.

Okebukola, P. A., \& Jegede, O. J. (1992). Survey of factors that stress science teachers and an examination of coping strategies. Science Education, 76(2), 199-210.

Ouellette, R. R., Frazier, S. L., Shernoff, E. S., Cappella, E., Mehta, T. G., Maríñez-Lora, A., Cua, G., \& Atkins, M. S. (2018). Teacher Job Stress and Satisfaction in Urban Schools: Disentangling Individual-, Classroom-, and Organizational-Level Influences. Behavior Therapy, 49, 494-508. https://doi.org/10.1016/j.beth.2017.11.011.

Pogere, E. F., López-Sangil, M. C., García-Señorán, M. M., \& González, A. (2019). Teachers' job stressors and coping strategies: Their structural relationships with emotional exhaustion and autonomy support. Teaching and Teacher Education, 85, 269-280. https://doi.org/10.1016/j.tate.2019.07.001.

Putri, M., Rahmaniar S.P., A., \& Djayanti, F. (2020). Risk factor analysis of work stress and muscle pain among high school teachers in Makassar. Enfermería Clínica, 30, 444-448. https://doi.org/10.1016/j.enfcli.2019.07.134.

Robbins, S. P. (1998). Organizational Behavior: Concepts, Controversies, Applications (8th edition). Prentice Hall.

Shimazu, A., Okada, Y., Sakamoto, M., \& Miura, M. (2003). Effects of stress management program for teachers in Japan: A pilot study. Journal of Occupational Health, 45(4), 202-208.

Taylor, M., McLean, L., Bryce, C. I., Abry, T., \& Granger, K. L. (2019). The influence of multiple life stressors during Teacher Training on Burnout and Career Optimism in the first year of teaching. Teaching and Teacher Education, 86, 102910. https://doi.org/10.1016/j.tate.2019.102910.

Vertanen-Greis, H., Loyttyniemi, E., Uitti, J., \& Putus, T. (2020). Work ability of teachers associated with voice disorders, stress, and the indoor environment: A questionnaire study in Finland. Journal of Voice. https://doi.org/10.1016/j.jvoice.2020.09.022.

Weinstein, T. L., \& Trickett, E. J. (2016). The Development of An Instrument to Measure English Language Learner (ELL) Teacher Work Stress. Teaching and Teacher Education, 55, 24-32. https://doi.org/10.1016/j.tate.2015.12.001. 
Wu, D. (2020). Relationship between Job Burnout and Mental Health of Teachers under Work Stress. Revista Argentina de Clinica Psicologica, 29(1), 310-315. https://doi.org/10.24205/03276716.2020.41.

Wu, P.-L., Tseng, S.-M., Tseng, Y.-C., Chen, L.-C., Pai, H.-C., \& Yen, W.-J. (2021). Job stress and occupational burnout among clinical nursing teachers: A cross-sectional study. Journal of Professional Nursing, 37(5), 907-915. https://doi.org/10.1016/j.profnurs.2021.07.014.

Zhong, J., You, J., Gan, Y., Zhang, Y., Lu, C., \& Wang, H. (2009). Job Stress, Burnout, Depression Symptoms, and Physical Health among Chinese University Teachers. Psychological Reports, 105(3), 1248-1254. https://doi.org/10.2466/PR0.105.F.1248-1254. 